\title{
KEEFEKTIFAN PENAMBAHAN KAPASITAS SALURAN DAN DINDING PENAHAN TANAH PADA SUNGAI BRANTAS HULU DI KEDIRI DALAM MITIGASI BANJIR
}

\author{
Rian Mantasa Salve Prastica ${ }^{1)}$, Dhany Saputra Pratama ${ }^{2)}$, \\ Muhammad Rizki Primasetya ${ }^{3)}$ \\ ${ }^{1,2,3)}$ Departemen Teknik Sipil, Universitas Gadjah Mada, Yogyakarta, 55281, Indonesia \\ email: rian.mantasa.s.p@ugm.ac.id ${ }^{1)^{*}}$, dhany.saputra.pratama@mail.ugm.ac.id ${ }^{2)}$, \\ $\underline{\text { m.rizki.primasetya@mail.ugm.ac.id }}^{3)}$
}

DOI: http://dx.doi.org/10.29103/tj.v10i2.287

(Received: March 2020 / Revised: July 2020 / Accepted: August 2020)

\begin{abstract}
Abstrak
Mitigasi banjir merupakan hal penting dilakukan pada wilayah terdampak bencana, misalnya saluran, sungai, drainase, dan lain-lain, namun, perlu dilakukan penilaian terlebih dahulu agar mitigasi yang dilakukan bersifat efektif. Penelitian ini berfokus di Sungai Brantas bagian hulu di Kediri. Evaluasi pentingnya pelebaran saluran dan pembangunan dinding penahan tanah di kawasan tersebut perlu dilakukan karena dinilai tidak efektif. Penelitian ini menggunakan metode penelitian yang terdiri dari analisis banjir, analisis stabilitas lereng, dan evaluasi skenario baru yang diwacanakan pada saluran yang ditinjau. Berdasarkan hasil analisis hidrologi, pemodelan hidrolika menggunakan HEC-RAS, analisis stabilitas lereng menggunakan SLOPE/W, dan simulasi skenario baru menyimpulkan bahwa intervensi penambahan dimensi kapasitas saluran dan penambahan perkuatan lereng tidak efektif pada Sungai Brantas bagian hulu yang memiliki frekuensi kejadian banjir yang sedikit.
\end{abstract}

Kata kunci: analisis banjir wilayah perkotaan, analisis dinding penahan tanah, keefektifan skenario mitigasi banjir

\begin{abstract}
Flood mitigation is an important thing to do in areas affected by disasters, such as canals, rivers, drainage, and others. However, it is necessary to do an assessment first so that the mitigation undertaken is effective. This research focuses on the upstream Brantas River in Kediri. Evaluation of the importance of channel widening and construction of retaining walls in the area needs to be done because it is considered ineffective. This study uses a research method consisting of flood analysis, slope stability analysis, and evaluation of new scenarios that are planned on the channel being reviewed. Based on the results of hydrological analysis, hydraulic modeling using HEC-RAS, slope stability analysis using SLOPE/W, and a new scenario simulation concluded that the intervention of adding channel capacity dimensions and the addition of slope reinforcement was ineffective in the upstream Brantas River which had a low frequency of flood events.
\end{abstract}

Keywords: urban flood analysis, retaining wall analysis, flood mitigation scenario effectiveness

Keefektifan Penambahan Kapasitas Saluran Dan Dinding Penahan Tanah Pada Sungai Brantas Hulu Di Kediri Dalam Mitigasi Banjir - Rian Mantasa Salve Prastica, Dhany Saputra Pratama, Muhammad Rizki Primasetya 


\section{Latar Belakang}

Banjir merupakan bencana yang disebabkan oleh air atau water-related disaster yang disebabkan oleh beragam faktor seperti pemanasan global, perubahan iklim, dan perubahan tata guna lahan (Paprotny et al., 2018; Smith et $a l ., 2019)$ yang pada akhirnya meningkatkan frekuensi banjir, seperti banjir New York pada tahun 2011, banjir di Houston pada tahun 2017, banjir di China tahun 2018, dan banjir di Brazil tahun 2019 (Wu et al., 2020). Tidak lupa dengan banjir di Indonesia setiap tahunnya, seperti banjir di Bojonegoro (Prastica et al., 2018), banjir di Yogyakarta (R. M.S. Prastica and Wicaksono, 2019), dan tentu banjir yang menjadi sorotan publik pada awal tahun 2020 di beberapa bagian di Indonesia yang rentan akan banjir, misalnya Jakarta dan Bogor. Dalam melakukan analisis kerentanan suatu daerah aliran sungai (DAS), dapat dilakukan penilaian pada beberapa aspek seperti infrastruktur, lingkungan, dan makhluk hidup yang ada (Setyoasri and Prastica, 2020).

Dalam mengatasi suatu kejadian bencana, idealnya pemerintah setempat selaku pihak yang berwenang dapat melakukan mitigasi bencana. Payung besar penelitian ini adalah analisis banjir di Blitar dan Kediri. Namun, pada penelitian ini, hanya terfokus pada analisis banjir Sungai Brantas bagian hulu di Kediri.

Kajian mitigasi bencana telah banyak dilakukan oleh penelitian sebelumnya. Beberapa penelitian merekomendasikan adanya infrastruktur hijau yang dapat diterapkan di suatu kota untuk mereduksi banjir (Liu and Li, 2016; Kourtis, Tsihrintzis and Baltas, 2018; Machado, Oliveira and Lois-González, 2019; Prastica, Apriatresnayanto and Marthanty, 2019). Namun, beberapa penelitian menyimpulkan bahwa pembangunan infrastruktur fisik seperti bendungan dan intervensi pada hidrolika bangunan air juga dapat mereduksi dampak banjir yang terjadi (Nieto et al., 2013; Wedawatta et al., 2016; Prastica et al., 2017; Tedford and Ellison, 2018; Yazdi, 2018).

Penelitian ini menyelaraskan rencana yang akan dilakukan pemangku kepentingan yaitu pelebaran dimensi saluran dan pembuatan dinding penahan tanah. Namun, sesuai dengan kejadian di lapangan, Sungai Brantas bagian hulu memiliki frekuensi banjir yang kecil dibandingkan bagian hilirnya, sehingga asumsi awal dinilai tidak diperlukannya pembangunan infrastruktur di sungai bagian itu. Akhirnya, penelitian ini bertujuan untuk mengevaluasi kondisi hidrolika Sungai Brantas bagian hulu terkait kapasitasnya dalam menampung debit banjir yang terjadi dan kondisi stabilitas lereng pada kondisi eksisting. Selain itu, penelitian ini juga mengevaluasi keefektifan penambahan dimensi saluran dan pembangunan dinding penahan tanah baru pada tanggul saluran.

\section{Metode Penelitian}

Dalam penelitian ini, metode yang digunakan telah banyak digunakan pula di penelitian-penelitian sejenis sebelumnya. Penelitian ini memiliki tiga komponen penelitian utama, yaitu (1) analisis banjir hidrologi dan pemodelan hidrolika, (2) analisis stabilitas lereng, dan (3) evaluasi pelebaran dimensi saluran dan pembuatan dinding penahan tanah.

Pada tahapan analisis banjir, data curah hujan perlu didapatkan di wilayah DAS yang ditinjau, kemudian dilakukan analisis curah hujan yang terdiri dari analisis hujan wilayah menggunakan metode Thiessen, analisis frekuensi dan

Keefektifan Penambahan Kapasitas Saluran Dan Dinding Penahan Tanah Pada Sungai Brantas Hulu Di Kediri Dalam Mitigasi Banjir - Rian Mantasa Salve Prastica, Dhany Saputra Pratama, Muhammad Rizki Primasetya 
validitas data hujan, dan analisis intensitas hujan. Akhirnya, baru bisa dilakukan analisis debit rancangan menggunakan metode hidrograf satuan sintesis (HSS) Nakayasu, sesuai dengan tahapan pada penelitian lainnya (Kang et al., 2009; Prastica et al., 2017, 2018). Persamaan umum HSS Nakayasu adalah seperti tertera pada Persamaan 1 berikut.

$$
Q_{p}=\frac{C x R_{0}}{3,6 x\left(0,3 x T_{p}+T_{0,3}\right)}
$$

di mana

$\mathrm{Q}_{\mathrm{p}}=$ debit banjir rancangan $\left(\mathrm{m}^{3} /\right.$ detik $)$

$\mathrm{R}_{0}=$ hujan satuan (mm)

$\mathrm{T}_{\mathrm{p}}=$ gap waktu dari awal hujan sampai banjir puncak

$\mathrm{T}_{0,3}=$ waktu penurunan debit dari puncak sampai $30 \%$ dari debit puncak

$\mathrm{C}=$ luas DAS sampai outlet $\left(\mathrm{km}^{2}\right)$

Setelah mendapatkan hasil debit puncak, disimulasikan pada kondisi saluran hidrolika eksisting dengan bantuan program HEC-RAS (Drake, Bradford and Joy, 2010; Rao and Hromadka, 2016; Zellou and Rahali, 2017; Kumar et al., 2019; Rangari, Umamahesh and Bhatt, 2019).

Tahapan analisis stabilitas lereng pada tanggul saluran kondisi eksisting dilakukan menggunakan perangkat lunak Geo-Studio yang memiliki fitur SLOPE/W yang dapat dimanfaatkan dalam menganalisis stabilitas lereng (GEOSLOPE International Ltd., 2012). Hasil akhir analisis ini adalah faktor keamanan tanggul atau lereng eksisting.

Tahapan akhir dalam penelitian ini adalah analisis skenario pelebaran dimensi saluran dan penambahan dinding penahan tanah (DPT). Analisis selanjutnya dilakukan kembali menggunakan HEC-RAS untuk visualisasi profil muka banjir dan Geo-Studio untuk menganalisis stabilitas lereng dengan penambahan DPT. Hasil akhir kemudian dievaluasi antara kondisi eksisting dan skenario baru.

\section{Hasil dan Pembahasan}

Analisis awal yang dilakukan dalam observasi banjir adalah analisis hidrologi seperti analisis curah hujan pada daerah aliran sungai (DAS) yang ditinjau. Pada penelitian ini, daerah tinjauan yang dianalisis adalah DAS Brantas bagian hulu, tepatnya di Kota Kediri. Gambar 1 menunjukkan DAS Brantas. Dalam kasus penelitian ini, diperoleh data curah hujan dari tiga stasiun hujan, yaitu Stasiun Geofisika Sawahan, Stasiun Meteorologi Juanda, dan Stasiun Klimatologi Malang, seperti yang terlihat pada Gambar 2. Dalam proses pengumpulan data hujan pada penelitian ini, ditemukan beberapa data curah hujan harian yang kosong sehingga analisis hidrologi menggunakan data curah hujan maksimum pada DAS. Data hujan yang dikumpulkan dari ketiga stasiun hujan berupa data hujan harian sepanjang tahun selama 10 tahun (2009-2018). Pada Gambar 2, terlihat analisis curah hujan yang terjadi pada daerah tinjauan menggunakan metode Thiessen. Berdasarkan hasil pengolahan data curah hujan harian maksimum tahunan dari tahun 2009 sampai tahun 2018 pada ketiga stasiun

Keefektifan Penambahan Kapasitas Saluran Dan Dinding Penahan Tanah Pada Sungai Brantas Hulu Di Kediri Dalam Mitigasi Banjir - Rian Mantasa Salve Prastica, Dhany Saputra Pratama, Muhammad Rizki Primasetya 
hujan, diperoleh data sesuai dengan Tabel 1 dan luasan wilayah DAS seperti yang tertera pada Tabel 2.

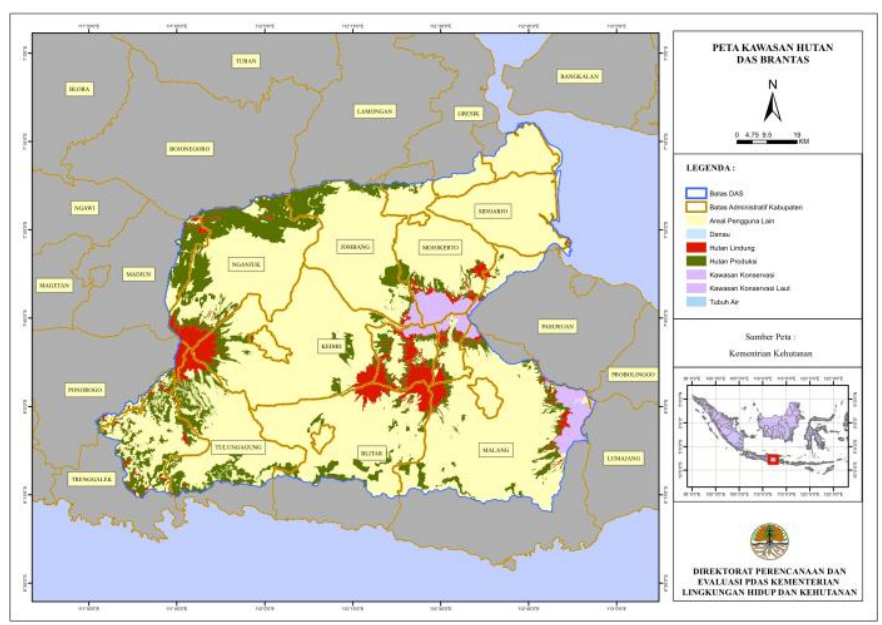

Gambar 1 Peta daerah aliran sungai Brantas (Direktorat Perencanaan dan Evaluasi PDAS, 2015)

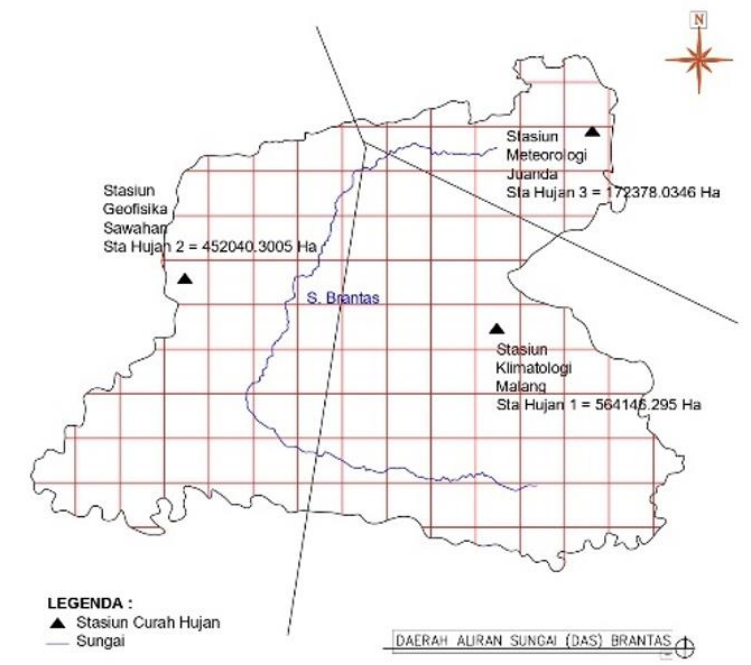

Gambar 2 Peta stasiun hujan dalam metode Thiessen

Tabel 1 Curah hujan harian maksimum tahunan DAS tinjauan

\begin{tabular}{cccc}
\hline Tahun & Sta $\mathbf{1}(\mathbf{m m})$ & Sta $\mathbf{2}(\mathbf{m m})$ & Sta $\mathbf{3}(\mathbf{m m})$ \\
\hline 2009 & 15,57 & 22,05 & 7,18 \\
\hline 2010 & 17,63 & 30,36 & 5,89 \\
\hline 2011 & 10,94 & 21,95 & 7,03 \\
\hline 2012 & 15,55 & 19,16 & 7,33 \\
\hline 2013 & 15,54 & 21,34 & 8,04 \\
\hline 2014 & 12,33 & 27,04 & 8,20 \\
\hline 2015 & 15,65 & 31,89 & 8,95 \\
\hline 2016 & 24,94 & 32,79 & 7,37 \\
\hline 2017 & 14,66 & 27,14 & 7,74 \\
\hline 2018 & 15,15 & 22,67 & 7,73 \\
\hline
\end{tabular}

Keefektifan Penambahan Kapasitas Saluran Dan Dinding Penahan Tanah Pada Sungai Brantas Hulu Di Kediri Dalam Mitigasi Banjir - Rian Mantasa Salve Prastica, Dhany Saputra Pratama, Muhammad Rizki Primasetya 
Tabel 2 Luasan wilayah Thiessen pada DAS

\begin{tabular}{ccc}
\hline Sta & Luas (ha) & Persentase \\
\hline Sta 1 & $564.146,295$ & 0,47 \\
\hline Sta 2 & $452.040,301$ & 0,38 \\
Sta 3 & $172.378,035$ & 0,15 \\
\hline Total & $1.188 .564,63$ & 1,00
\end{tabular}

Berdasarkan Tabel 1 dan Tabel 2, dapat dianalisis hujan wilayah yang terjadi pada DAS, sesuai dengan Tabel 3, sebelum diolah pada analisis frekuensi curah hujan.

Tabel 3 Hujan wilayah metode Thiessen

\begin{tabular}{cccccc}
\hline Tahun & $\mathbf{P 1}(\mathbf{m m})$ & $\mathbf{P 2}(\mathbf{m m})$ & $\mathbf{P 3}(\mathbf{m m})$ & Rata-rata & $\begin{array}{c}\text { Urutan }(\mathbf{M i n}- \\
\text { Max })\end{array}$ \\
\hline 2009 & 7,39 & 8,39 & 1,04 & 5,61 & 4,85 \\
\hline 2010 & 8,37 & 11,55 & 0,85 & 6,92 & 5,24 \\
\hline 2011 & 5,19 & 8,35 & 1,02 & 4,85 & 5,55 \\
\hline 2012 & 7,38 & 7,29 & 1,06 & 5,24 & 5,61 \\
\hline 2013 & 7,38 & 8,12 & 1,17 & 5,55 & 5,64 \\
\hline 2014 & 5,85 & 10,28 & 1,19 & 5,77 & 5,77 \\
\hline 2015 & 7,43 & 12,13 & 1,30 & 6,95 & 6,13 \\
\hline 2016 & 11,84 & 12,47 & 1,07 & 8,46 & 6,92 \\
\hline 2017 & 6,96 & 10,32 & 1,12 & 6,13 & 6,95 \\
\hline 2018 & 7,19 & 8,62 & 1,12 & 5,64 & 8,46 \\
\hline
\end{tabular}

Analisis frekuensi curah hujan dilakukan menggunakan metode Gumbel dan Log-Pearson tipe III. Setelah itu, dilakukan uji validitas dengan metode uji Chisquare dan Smirnov Kalmogorov. Kedua uji validitas menyatakan bahwa baik metode Gumbel dan Log Pearson tipe III dapat diterima, seperti yang terlihat pada Tabel 4. Berdasarkan hasil yang diperoleh, diambil nilai yang lebih besar, yaitu menggunakan metode Gumbel. Hasil analisis frekuensi inilah yang akan diproses lebih lanjut ke analisis banjir rancangan dalam analisis hidrologi.

Tabel 4 Rekapitulasi uji validitas data curah hujan kala ulang (mm)

\begin{tabular}{cccc}
\hline Kala ulang & Gumbel & $\begin{array}{c}\text { Log pearson } \\
\text { III }\end{array}$ & $\begin{array}{c}\text { Hujan } \\
\text { Rencana }\end{array}$ \\
\hline R2 & 6,011 & 5,890 & 6,011 \\
\hline R5 & 7,276 & 6,865 & 7,276 \\
R10 & 8,114 & 7,551 & 8,114 \\
\hline R25 & 9,173 & 8,453 & 9,173 \\
R50 & 9,959 & 9,156 & 9,959 \\
\hline R100 & 10,738 & 9,856 & 10,738 \\
\hline R500 & 12,541 & 10,934 & 12,541 \\
\hline R1000 & 13,316 & 12,450 & 13,316 \\
\hline Hasil uji chi-kuadrat & Diterima & Diterima & \\
\hline
\end{tabular}

Keefektifan Penambahan Kapasitas Saluran Dan Dinding Penahan Tanah Pada Sungai Brantas Hulu Di Kediri Dalam Mitigasi Banjir - Rian Mantasa Salve Prastica, Dhany Saputra Pratama, Muhammad Rizki Primasetya 
Analisis banjir dilakukan dengan menggunakan metode Nakayasu dengan diawali dengan analisis intensitas hujan menggunakan metode Mononobe. Gambar 3 merupakan hasil analisis intensitas hujan dalam bentuk grafik IDF (intensity-duration-frequency). Dari pengolahan analisis data dengan metode Nakayasu, debit banjir yang terjadi pada DAS terlihat pada Tabel 5.

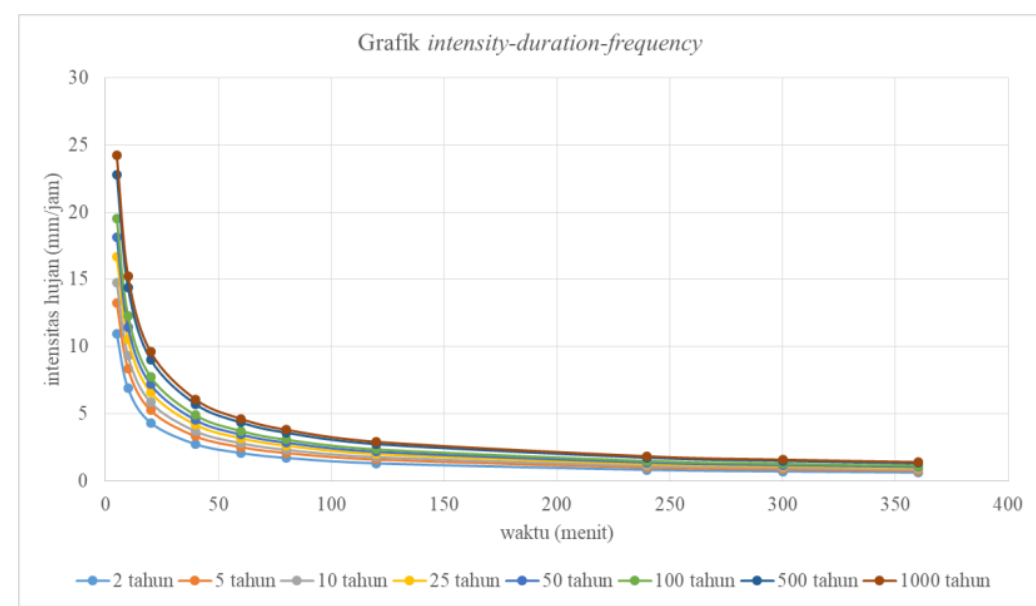

Gambar 3 Analisis intensitas hujan metode Mononobe

Hasil debit banjir rancangan perlu dilakukan kalibrasi dalam hidrologi, namun data AWLR (Automatic Water Level Recorder) pada DAS tinjauan tidak tersedia. Sehingga, proses validasi debit banjir untuk analisis dilakukan dengan studi literatur pada DAS tinjauan yang sama. Studi yang dilakukan oleh Kuncoro dkk. (Kuncoro, Winarto and Purnomo, 2018) menyebutkan bahwa banjir rancangan 25 tahun pada DAS studi adalah minimum 165,321 $\mathrm{m}^{3} /$ detik dan maksimum 202,475 $\mathrm{m}^{3} /$ detik. Sedangkan studi yang dilakukan oleh Erlina (Erlina, 2018) menyatakan debit bervariasi dari minimum 795,564 $\mathrm{m}^{3} /$ detik sampai $1356,301 \mathrm{~m}^{3} /$ detik. Ditambah, hasil studi Kementerian Pekerjaan Umum (Kementerian Pekerjaan Umum, 2010) mengenai Pengelolaan Sumber Daya Air Wilayah Sungai Brantas menyatakan debit banjir kala ulang pada DAS tinjauan bagian hulu adalah 193,694 $\mathrm{m}^{3} /$ detik; 248,479 $\mathrm{m}^{3} /$ detik; 284,109 $\mathrm{m}^{3} /$ detik; $328,625 \mathrm{~m}^{3} /$ detik; 361,506 m³/detik; dan 394,371 $\mathrm{m}^{3} /$ detik untuk $\mathrm{Q}_{2}, \mathrm{Q}_{5}, \mathrm{Q}_{10}, \mathrm{Q}_{25}$, $\mathrm{Q}_{50}$, dan $\mathrm{Q}_{100}$. Berdasarkan hasil studi penelitian terdahulu, hasil analisis debit yang digunakan pada penelitian ini pada DAS tinjauan bisa tervalidasi.

Tabel 5 Debit puncak banjir rancangan kala ulang

\begin{tabular}{cc}
\hline Kala ulang & $\begin{array}{c}\text { Debit puncak } \\
\left(\mathbf{m}^{\mathbf{3}} / \mathbf{d e t i k}\right)\end{array}$ \\
\hline 2 tahun & 185,878 \\
\hline 5 tahun & 241,078 \\
\hline 10 tahun & 281,344 \\
\hline 25 tahun & 348,120 \\
\hline 50 tahun & 402,686 \\
\hline 100 tahun & 470,422 \\
\hline 500 tahun & 645,086 \\
\hline 1000 tahun & 814,699 \\
\hline
\end{tabular}

Keefektifan Penambahan Kapasitas Saluran Dan Dinding Penahan Tanah Pada Sungai Brantas Hulu Di Kediri Dalam Mitigasi Banjir - Rian Mantasa Salve Prastica, Dhany Saputra Pratama, Muhammad Rizki Primasetya 
Evaluasi kapasitas saluran pada DAS yang ditinjau kemudian dinilai berdasarkan debit puncak yang terjadi dan kondisi hidrolika saluran eksisting. Berdasarkan data pengamatan di lapangan, Tabel 6 dan Gambar 4 menyajikan kondisi hidrolika saluran eksisting.

Tabel 6. Kondisi hidrolika saluran eksisting

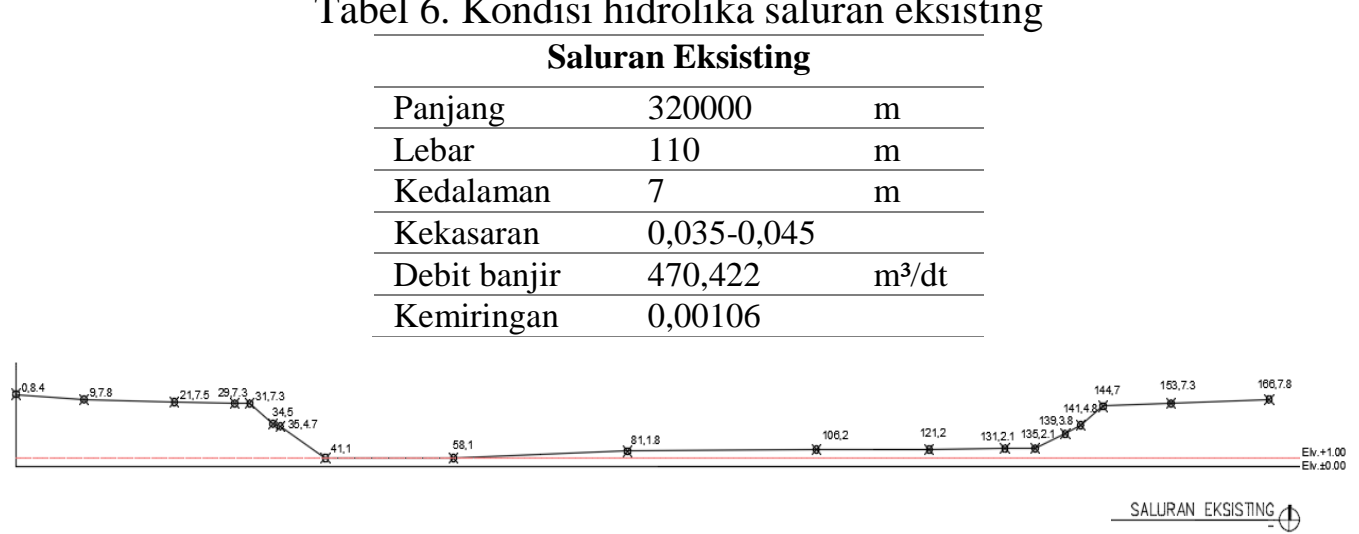

Gambar 4 Saluran eksisting pada daerah tinjauan

Berdasarkan Gambar 4 dan data Tabel 6, dibuat simulasi model dengan bantuan perangkat lunak HEC-RAS dengan rincian koordinat dimensi hidrolika saluran seperti pada Tabel 7. Analisis HEC-RAS dapat membantu menampilkan visualisasi apakah kapasitas sungai masih mendukung debit banjir yang terjadi pada DAS tinjauan seperti penelitian yang dilakukan di berbagai negara (Ben Khalfallah and Saidi, 2018; Parhi, 2018; Kumar et al., 2019; R.M.S. Prastica and Wicaksono, 2019; Rangari et al., 2019). Hal ini menunjukkan keandalan HECRAS dalam simulasi.

Tabel 7 Koordinat Cross section penampang hilir dan hulu saluran eksisting

\begin{tabular}{ccc}
\hline \multicolumn{3}{c}{ Cross Section } \\
\hline $\mathbf{x}$ & $\mathbf{y}$ (hilir) & $\mathbf{y}$ (hulu) \\
\hline 0 & 7,4 & 76,4 \\
\hline 9 & 6,8 & 75,8 \\
\hline 21 & 6,5 & 75,5 \\
\hline 29 & 6,3 & 75,3 \\
\hline 31 & 6,3 & 75,3 \\
\hline 34 & 4,0 & 73,0 \\
\hline 35 & 3,7 & 72,7 \\
\hline 41 & 0,0 & 69,0 \\
\hline 58 & 0,0 & 69,0 \\
\hline 81 & 0,8 & 69,8 \\
\hline 106 & 1,0 & 70,0 \\
\hline 121 & 1,0 & 70,0 \\
\hline 131 & 1,1 & 70,1 \\
\hline 135 & 1,1 & 70,1 \\
\hline 139 & 2,8 & 71,8 \\
\hline 141 & 3,8 & 72,8 \\
\hline 144 & 6,0 & 75,0 \\
\hline 153 & 6,3 & 75,3 \\
\hline 166 & 6,8 & 75,8 \\
\hline
\end{tabular}

Keefektifan Penambahan Kapasitas Saluran Dan Dinding Penahan Tanah Pada Sungai Brantas Hulu Di Kediri Dalam Mitigasi Banjir - Rian Mantasa Salve Prastica, Dhany Saputra Pratama, Muhammad Rizki Primasetya 
Gambar 5 merupakan hasil simulasi kondisi saluran eksisting pada DAS tinjauan. Berdasarkan kondisi karakteristik hidrologi yang terjadi, saluran masih bisa mengakomodasi debit banjir yang terjadi pada bagian saluran hulu bagian paling hulu, tengah, dan hilir.

Analisis selanjutnya adalah penilaian faktor keamanan lereng pada saluran yang akan dilakukan menggunakan bantuan perangkat lunak Geo-Studio pada fitur SLOPE/W. Fitur ini dipilih berdasarkan kajian yang telah dilakukan oleh banyak penelitian (Shole and Belayneh, 2019; Yu et al., 2020). Tabel 8 menunjukkan hasil simulasi faktor keamanan yang terjadi pada lereng. Berdasarkan analisis, dihasilkan faktor keamanan dengan rentang nilai 2,20 - 3,10 yang masih dapat dikategorikan sebagai kondisi aman.
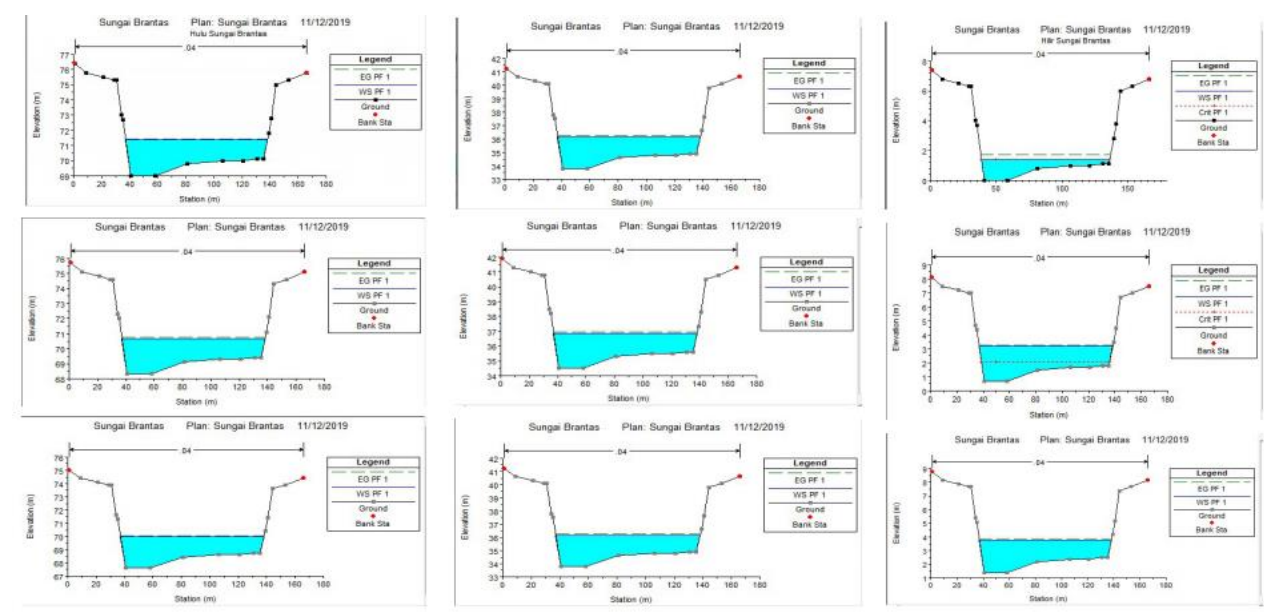

Gambar 5 Profil muka air saluran eksisting DAS tinjauan

Berdasarkan analisis kondisi eksisting, saluran pada DAS tinjauan belum waktunya diadakan penambahan kapasitas saluran atau perkuatan lereng untuk stabilitas sempadan kiri dan kanan saluran. Wacana pihak berwenang atau pemerintah untuk menambah kapasitas saluran dan menambah dinding penahan tanah pada saluran kemudian akan dianalisis pada penelitian ini.

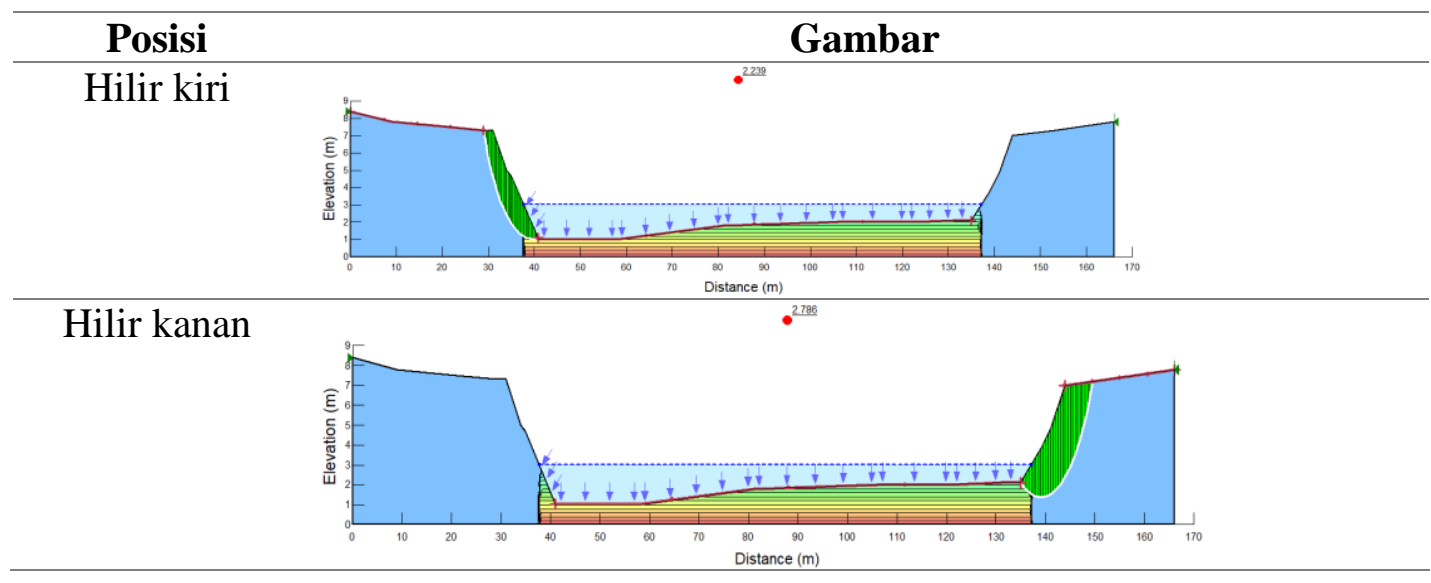

Keefektifan Penambahan Kapasitas Saluran Dan Dinding Penahan Tanah Pada Sungai Brantas Hulu Di Kediri Dalam Mitigasi Banjir - Rian Mantasa Salve Prastica, Dhany Saputra Pratama, Muhammad Rizki Primasetya 


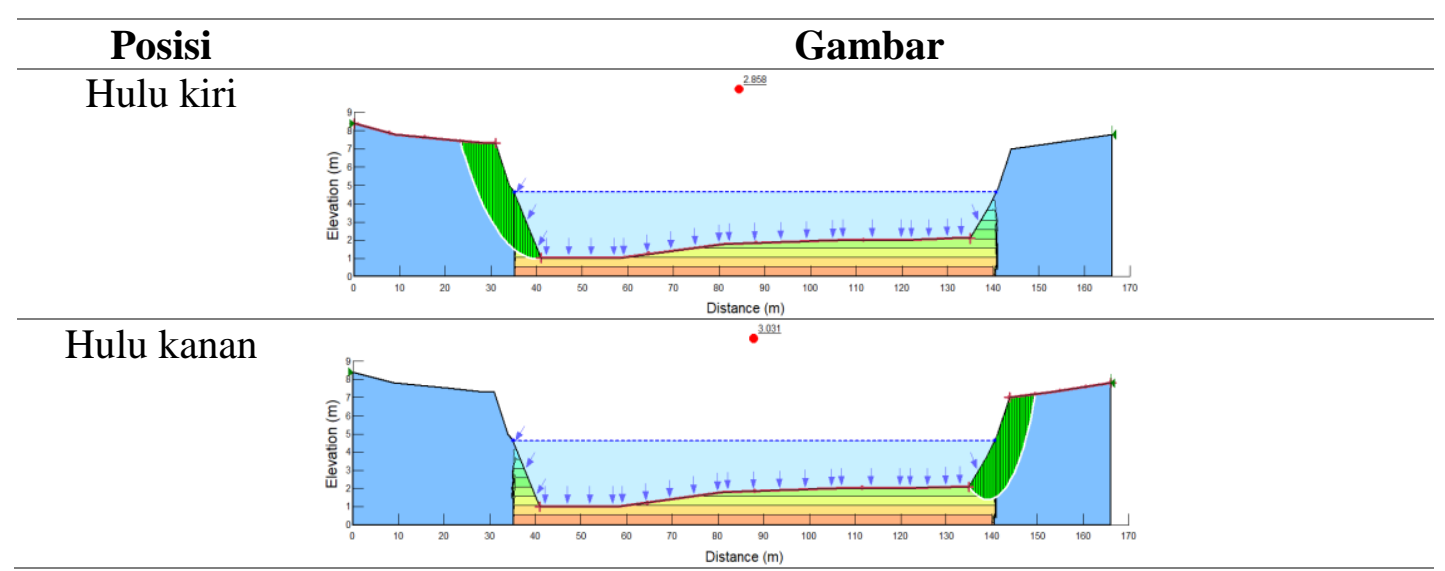

Gambar 6 Stabilitas kondisi lereng saluran eksisting

Tabel 8 dan Tabel 9 menjelaskan saluran yang merupakan perencanaan dan analisis terhadap saluran baru berbentuk persegi yang diberi dinding penahan tanah (DPT) untuk menstabilkan lereng tanggul.

Tabel 8 Desain hidrolika saluran baru

Saluran Desain dengan DPT Empat

Persegi Panjang

\begin{tabular}{lcc}
\hline Panjang & 320000 & $\mathrm{~m}$ \\
\hline Lebar & 113,02 & $\mathrm{~m}$ \\
\hline Kedalaman & 6,3 & $\mathrm{~m}$ \\
\hline Kekasaran & $0,035-0,045$ & \\
\hline Debit banjir & 470,422 & $\mathrm{~m}^{3} / \mathrm{dt}$ \\
\hline Kemiringan & 0,00106 & \\
\hline
\end{tabular}

Tabel 9 Koordinat Cross section saluran baru

\begin{tabular}{ccc}
\hline \multicolumn{3}{c}{ Cross Section } \\
\hline $\mathbf{X}$ & $\mathbf{y}$ (hilir) & $\mathbf{y}$ (hulu) \\
\hline 0 & 7,4 & 76,4 \\
\hline 9 & 6,8 & 75,8 \\
\hline 21 & 6,5 & 75,5 \\
\hline 29 & 6,3 & 75,3 \\
\hline 30 & 6,3 & 75,3 \\
\hline 31 & 6,3 & 75,3 \\
\hline 31 & 1,1 & 70,1 \\
\hline 32 & 0,5 & 69,5 \\
\hline 32 & 0,0 & 69,0 \\
\hline 58 & 0,0 & 69,0 \\
\hline 81 & 0,8 & 69,8 \\
\hline 106 & 1,0 & 70,0 \\
\hline 121 & 1,0 & 70,0 \\
\hline 131 & 1,1 & 70,1 \\
\hline 144 & 1,1 & 70,1 \\
\hline 144 & 6,3 & 75,3 \\
\hline 145 & 6,3 & 75,3 \\
\hline 145 & 6,0 & 75,0 \\
\hline 153 & 6,3 & 75,3 \\
\hline 166 & 6,8 & 75,8 \\
\hline
\end{tabular}

Keefektifan Penambahan Kapasitas Saluran Dan Dinding Penahan Tanah Pada Sungai Brantas Hulu Di Kediri Dalam Mitigasi Banjir - Rian Mantasa Salve Prastica, Dhany Saputra Pratama, Muhammad Rizki Primasetya 
Berdasarkan tampang saluran desain baru pada Tabel 9, maka debit yang dihasilkan adalah $2.745,15 \mathrm{~m}^{3} /$ detik. Dalam perancangan saluran baru, diberikan dinding penahan tanah pada kedua sisi saluran. Perancangan desain dinding penahan tanah dianalisis dengan hasil analisis sebagai berikut.

- Kedalaman Sungai $(\mathrm{H})$ $=7,3$ meter

- Panjang Puncak DPT

$=\mathrm{H} / 12$ atau 0,3 meter

- Panjang Puncak DPT

$=7,3 / 12$

$=0,608333 \mathrm{~m}$

- Tinggi Ujung kaki/Tumit DPT (D) $=1 / 8 \mathrm{H}$

- Tinggi Ujung kaki/Tumit DPT (D) $=1 / 8.7,3$

$=0,925 \mathrm{~m}$

atau

- Tinggi Ujung kaki/Tumit DPT (D) $=1 / 6 \mathrm{H}$

- Tinggi Ujung kaki DPT/Tumit (D) $=1 / 6.7,3$

$=1,17 \mathrm{~m}$

- Panjang Ujung kaki DPT(1/2D - D) $=1 / 2 \mathrm{D}-\mathrm{D}$

- Panjang Alas DPT

$=0,585-1,17$

$=0,4 \mathrm{H}-0.7 \mathrm{H}$

$=2,92-5,11 \mathrm{~m}$

Dengan memproposionalkan hasil dimensi tersebut maka didapatkan desain rancangan dinding penahan tanah yang terlihat pada Gambar 7 sebagai berikut.

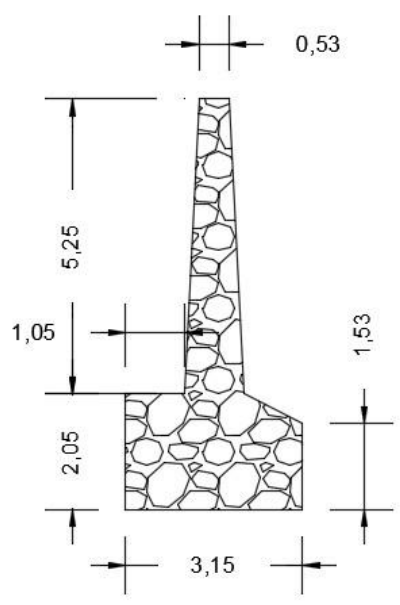

Gambar 7 Desain dinding penahan tanah baru

Setelah didapatkan dimensi dan desain dinding penahan tanah maka, dapat digambarkan pada saluran baru yang terlihat pada Gambar 8 sebagai berikut.

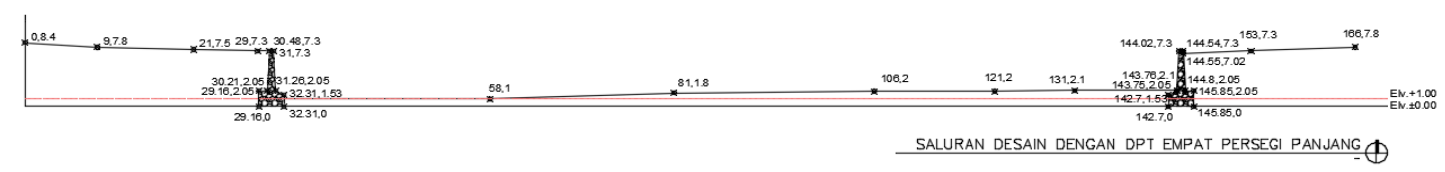

Gambar 8 Desain saluran baru dengan DPT

Keefektifan Penambahan Kapasitas Saluran Dan Dinding Penahan Tanah Pada Sungai Brantas Hulu Di Kediri Dalam Mitigasi Banjir - Rian Mantasa Salve Prastica, Dhany Saputra Pratama, Muhammad Rizki Primasetya 
Berdasarkan hasil analisis Kapasitas tampungan > debit kala ulang 100 tahun, $2745,15 \mathrm{~m}^{3} / \mathrm{dt}>470,422 \mathrm{~m}^{3} / \mathrm{dt}$, maka saluran baru dapat menampung debit banjir yang terjadi. Setelah diketahui profil muka air banjir pada saluran baru, maka dapat dilakukan analisis stabilitas lereng tanggul saluran menggunakan Geo-Studio dengan hasil pada Gambar 9.

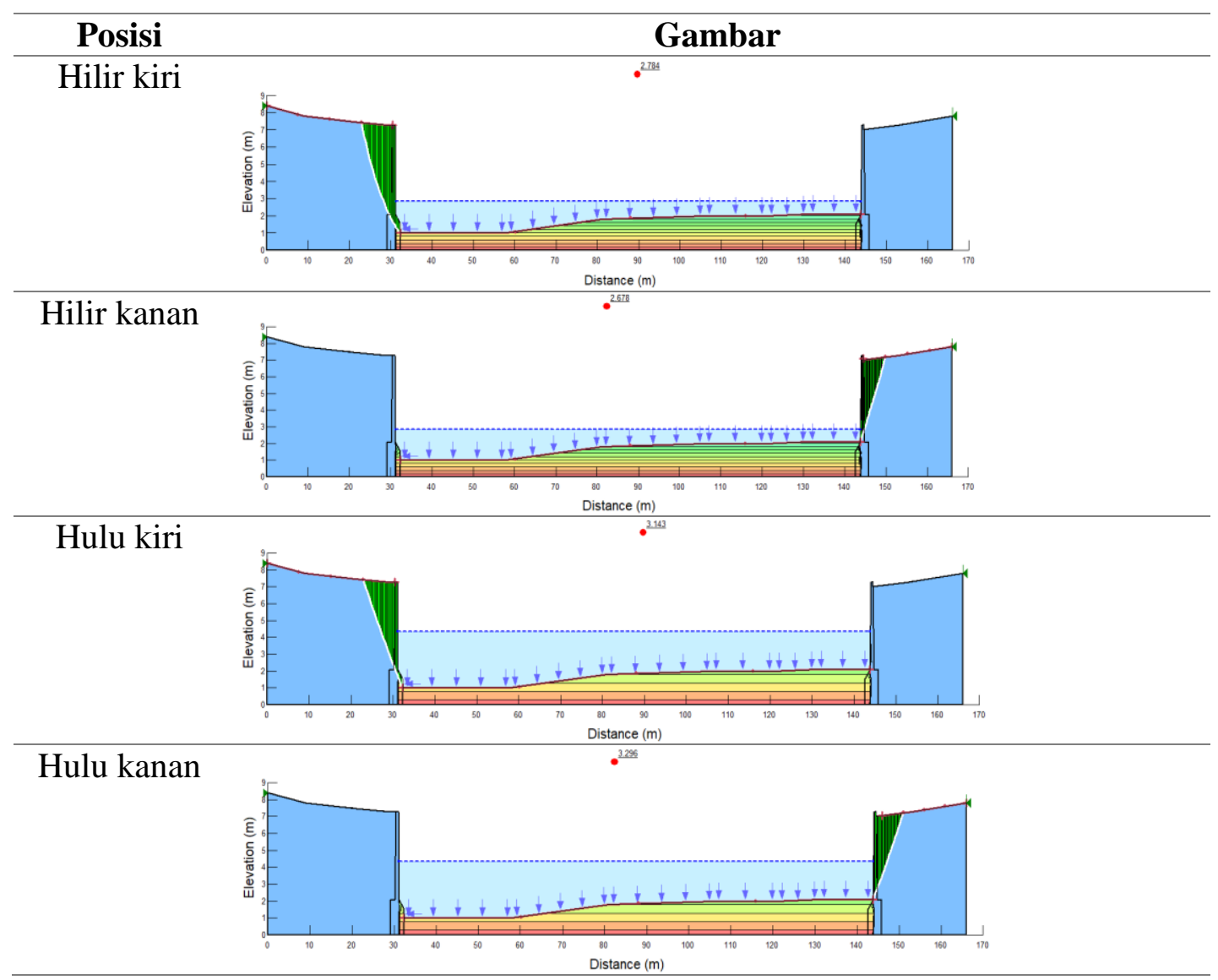

Gambar 9 Stabilitas kondisi lereng saluran baru dengan DPT

Setelah dilakukan analisis antara kondisi eksisting dan kondisi baru, maka dapat dilakukan rekapitulasi pada Tabel 10 mengenai kondisi hidrolika dan stabilitas lereng dalam menghadapi kondisi hidrologi DAS tinjauan. Berdasarkan analisis tersebut, penambahan DPT dan intervensi pelebaran dimensi saluran belum dinilai cukup penting pada saluran di DAS tinjauan. Dengan sedikitnya kasus atau laporan kejadian banjir di saluran tinjauan, maka kebijakan terkait pengubahan dimensi saluran dan penambahan DPT tidak efektif untuk dikerjakan.

Tabel 10 Rekapitulasi hasil analisis hidrolika dan stabilitas

\begin{tabular}{cccl}
\hline $\begin{array}{c}\text { Komponen } \\
\text { analisis }\end{array}$ & Kondisi eksisting & Kondisi baru & \multicolumn{1}{c}{ Penilaian } \\
\hline Debit maksimum & $470,422 \mathrm{~m}^{3} /$ detik & $2.745,15$ & Kondisi eksisiting masih \\
$\mathrm{m}^{3} / \mathrm{detik}$ & & $\begin{array}{l}\text { memenuhi kapasitas debit } \\
\text { banjir 100 tahunan di DAS, } \\
\text { penambahan dimensi saluran } \\
\text { dinilai kurang efektif. }\end{array}$ \\
\hline
\end{tabular}

Keefektifan Penambahan Kapasitas Saluran Dan Dinding Penahan Tanah Pada Sungai Brantas Hulu Di Kediri Dalam Mitigasi Banjir - Rian Mantasa Salve Prastica, Dhany Saputra Pratama, Muhammad Rizki Primasetya 


\begin{tabular}{lccl}
\hline \multicolumn{1}{c}{$\begin{array}{c}\text { Komponen } \\
\text { analisis }\end{array}$} & Kondisi eksisting & Kondisi baru & \multicolumn{1}{c}{ Penilaian } \\
\hline $\begin{array}{l}\text { Stabilitas lereng } \\
\text { minimum }\end{array}$ & 2,239 & 2,678 & $\begin{array}{l}\text { Nilai faktor keamanan } \\
\text { dengan atau tanpa DPT }\end{array}$ \\
& & & $\begin{array}{l}\text { menunjukkan perbedaan } \\
\text { yang tidak cukup signifikan, } \\
\end{array}$ \\
& & & $\begin{array}{l}\text { sehingga penambahan DPT } \\
\text { dinilai tidak efektif. }\end{array}$ \\
\hline
\end{tabular}

\section{Kesimpulan dan Saran}

\subsection{Kesimpulan}

Berdasarkan analisis dan simulasi numerik menggunakan perangkat lunak pendukung, sungai tinjauan Kota Kediri yang berada di kawasan DAS Brantas masih dapat mengakomodasi debit puncak banjir yang terjadi dengan stabilitas lereng yang masih berada pada rentang aman. Penambahan lebar saluran dan pembuatan dinding penahan tanah dinilai tidak efektif, sehingga belum saatnya dilakukan saat ini (tahun 2019-2020).

\subsection{Saran}

Analisis hidrologi perlu dilakukan kalibrasi sehingga keberadaan AWLR perlu mendapatkan perhatian bagi pemangku kebijakan agar mempermudah analisis di masa mendatang bagi pemerintah, peneliti, maupun pihak berkepentingan. Selain itu, perlu dilakukan evaluasi secara periodik dikarenakan dinamika iklim dan perubahan tata guna lahan yang dapat memengaruhi karakteristik hidrologi dan erosi yang terjadi. Evaluasi periodik membantu pemangku kebijakan memutuskan pembangunan fisik yang penting untuk wilayah yang rentan terhadap bencana. Selanjutnya, analisis perlu dilakukan di semua segmen Sungai Brantas bila mitigasi banjir secara struktural perlu dilakukan agar tidak ada upaya yang tidak efisien dilakukan.

\section{Ucapan Terima Kasih}

Peneliti mengucapkan terima kasih kepada Laboratorium Hidrolika dan Bangunan Air Departemen Teknik Sipil Sekolah Vokasi Universitas Gadjah Mada sehingga penelitian dapat diselesaikan dengan baik. Selain itu, penelitan ini mendapat dukungan dari Hibah Penelitian Dana Masyarakat Sekolah Vokasi Universitas Gadjah Mada tahun 2020.

\section{Daftar Kepustakaan}

Direktorat Perencanaan dan Evaluasi PDAS (2015) Kawasan DAS Brantas. Jakarta.

Drake, J., Bradford, A. and Joy, D. (2010) 'Application of HEC-RAS 4.0 temperature model to estimate groundwater contributions to Swan Creek, Ontario, Canada', Journal of Hydrology. Elsevier B.V., 389(3-4), pp. 390398. doi: 10.1016/j.jhydrol.2010.06.022.

Keefektifan Penambahan Kapasitas Saluran Dan Dinding Penahan Tanah Pada Sungai Brantas Hulu Di Kediri Dalam Mitigasi Banjir - Rian Mantasa Salve Prastica, Dhany Saputra Pratama, Muhammad Rizki Primasetya 
Erlina (2018) 'Analisis Banjir Dan Sedimentasi Wilayah Sungai Brantas (Tinjaun Terhadap Metode Pengendalian)', Jurnal Teknik Sipil, XIII(1), pp. 1-14. Available at: https://jurnal.ucy.ac.id/index.php/teknik_sipil/article/view/245.

GEO-SLOPE International Ltd. (2012) Stability Modeling with SLOPE / W. July 2012. Calgary, Alberta, Canada: GEO-SLOPE International Ltd. Available at: www.geo-slope.com.

Kang, M. S. et al. (2009) 'Design of drainage culverts considering critical storm duration', Biosystems Engineering. IAgrE, 104(3), pp. 425-434. doi: 10.1016/j.biosystemseng.2009.07.004.

Kementerian Pekerjaan Umum (2010) Pengelolaan Sumber Daya Air Wilayah Sungai Brantas.

Ben Khalfallah, C. and Saidi, S. (2018) 'Spatiotemporal floodplain mapping and prediction using HEC-RAS - GIS tools: Case of the Mejerda river, Tunisia', Journal of African Earth Sciences. Elsevier Ltd, 142, pp. 44-51. doi: 10.1016/j.jafrearsci.2018.03.004.

Kourtis, I. M., Tsihrintzis, V. A. and Baltas, E. (2018) 'Simulation of Low Impact Development (LID) Practices and Comparison with Conventional Drainage Solutions', Proceedings, 2(11), p. 640. doi: 10.3390/proceedings 2110640.

Kumar, N. et al. (2019) 'Applicability of HEC - RAS 2D and GFMS for flood extent mapping : a case study of Sangam area , Prayagraj , India', Modeling Earth Systems and Environment. Springer International Publishing, (0123456789). doi: 10.1007/s40808-019-00687-8.

Kuncoro, M. A., Winarto, S. and Purnomo, Y. C. S. (2018) 'Studi Penanggulangan Banjir di Kali Batan Kabupaten Kediri', Jurnal Manajemen Teknologi \& Teknik Sipil, 1(1). doi: 10.30737/jurmateks.v1i1.143.

Liu, C. and Li, Y. (2016) 'Measuring eco-roof mitigation on flash floods via GIS simulation', Built Environment Project and Asset Management, 6(4), pp. 415-427. doi: 10.1108/BEPAM-07-2015-0031.

Machado, R. A. S., Oliveira, A. G. and Lois-González, R. C. (2019) 'Urban ecological infrastructure: The importance of vegetation cover in the control of floods and landslides in Salvador / Bahia, Brazil', Land Use Policy. Elsevier, 89(October), p. 104180. doi: 10.1016/j.landusepol.2019.104180.

Nieto, J. M. et al. (2013) 'Acid mine drainage in the Iberian Pyrite Belt: 1. Hydrochemical characteristics and pollutant load of the Tinto and Odiel rivers', Environmental Science and Pollution Research, 20(11), pp. 75097519. doi: 10.1007/s11356-013-1634-9.

Paprotny, D. et al. (2018) 'Trends in flood losses in Europe over the past 150 years', Nature Communications. Springer US, 9(1). doi: 10.1038/s41467018-04253-1.

Parhi, P. K. (2018) 'Flood Management in Mahanadi Basin using HEC-RAS and Gumbel's Extreme Value Distribution', Journal of The Institution of Engineers (India): Series A. Springer India, 99(4), pp. 751-755. doi: 10.1007/s40030-018-0317-4.

Prastica, R. M. S. et al. (2017) 'Analisis Banjir dan Perencanaan Desain Transportasi Sungai di Kota Bojonegoro', Media Komunikasi Teknik Sipil, 23(2), p. 91. doi: 10.14710/mkts.v23i2.15981.

Keefektifan Penambahan Kapasitas Saluran Dan Dinding Penahan Tanah Pada Sungai Brantas Hulu Di Kediri Dalam Mitigasi Banjir - Rian Mantasa Salve Prastica, Dhany Saputra Pratama, Muhammad Rizki Primasetya 
Prastica, R. M. S. et al. (2018) 'Estimating design flood and HEC-RAS modelling approach for flood analysis in Bojonegoro city', in IOP Conference Series: Materials Science and Engineering. doi: 10.1088/1757-899X/316/1/012042.

Prastica, R. M. S., Apriatresnayanto, R. and Marthanty, D. R. (2019) 'Structural and green infrastructure mitigation alternatives prevent Ciliwung River from water-related landslide', International Journal on Advanced Science, Engineering and Information Technology, 9(6), pp. 1825-1832.

Prastica, R. M.S. and Wicaksono, D. (2019) 'Integrated multimodal disaster mitigation management for urban areas: A preliminary study for 2-d flood modeling, IOP Conference Series: Materials Science and Engineering, 650(1). doi: 10.1088/1757-899X/650/1/012056.

Prastica, R.M.S. and Wicaksono, D. (2019) 'Integrated multimodal disaster mitigation management for urban areas: A preliminary study for 2-d flood modeling, in IOP Conference Series: Materials Science and Engineering. doi: 10.1088/1757-899X/650/1/012056.

Rangari, V. A. et al. (2019) 'Floodplain Mapping and Management of Urban Catchment Using HEC-RAS: A Case Study of Hyderabad City', Journal of The Institution of Engineers (India): Series A. Springer India, 100(1), pp. 49-63. doi: 10.1007/s40030-018-0345-0.

Rangari, V. A., Umamahesh, N. V. and Bhatt, C. M. (2019) 'Assessment of inundation risk in urban floods using HEC RAS 2D', Modeling Earth Systems and Environment. Springer International Publishing, 5(4), pp. 1839-1851. doi: 10.1007/s40808-019-00641-8.

Rao, P. and Hromadka, T. V. (2016) 'Numerical modeling of rapidly varying flows using HEC-RAS and WSPG models', SpringerPlus. Springer International Publishing, 5(1). doi: 10.1186/s40064-016-2199-0.

Setyoasri, Y. P. and Prastica, R. M. S. (2020) 'Rapid assessment of river watershed health and vulnerability level for restoration strategy: a study of river systems in Indramayu, West Java, Indonesia', IOP Conference Series: Earth and Environmental Science, 423, p. 012016. doi: 10.1088/17551315/423/1/012016.

Shole, D. G. and Belayneh, M. Z. (2019) 'The effect of side slope and clay core shape on the stability of embankment dam: Southern Ethiopia', International Journal of Environmental Science and Technology. Springer Berlin Heidelberg, 16(10), pp. 5871-5880. doi: 10.1007/s13762-019022283.

Smith, A. et al. (2019) 'New estimates of flood exposure in developing countries using high-resolution population data', Nature Communications. Springer US, 10(1), pp. 1-7. doi: 10.1038/s41467-019-09282-y.

Tedford, M. and Ellison, J. C. (2018) 'Analysis of river rehabilitation success, Pipers River, Tasmania', Ecological Indicators. Elsevier, 91(September 2017), pp. 350-358. doi: 10.1016/j.ecolind.2018.03.090.

Wedawatta, G. et al. (2016) 'Disaster risk reduction infrastructure requirements for South-Western Bangladesh: Perspectives of local communities', Built Environment Project and Asset Management, 6(4), pp. 379-390. doi: 10.1108/BEPAM-06-2015-0022.

Keefektifan Penambahan Kapasitas Saluran Dan Dinding Penahan Tanah Pada Sungai Brantas Hulu Di Kediri Dalam Mitigasi Banjir - Rian Mantasa Salve Prastica, Dhany Saputra Pratama, Muhammad Rizki Primasetya 
Wu, Z. et al. (2020) 'Depth prediction of urban flood under different rainfall return periods based on deep learning and data warehouse', Science of the Total Environment. Elsevier B.V., 716, p. 137077. doi: 10.1016/j.scitotenv.2020.137077.

Yazdi, J. (2018) 'Rehabilitation of Urban Drainage Systems Using a ResilienceBased Approach'. Water Resources Management, pp. 721-734.

Yu, S. et al. (2020) 'Sensibility analysis of the hydraulic conductivity anisotropy on seepage and stability of sandy and clayey slope', Water (Switzerland), 12(1). doi: 10.3390/w12010277.

Zellou, B. and Rahali, H. (2017) 'Assessment of reduced-complexity landscape evolution model suitability to adequately simulate flood events in complex flow conditions', Natural Hazards. Springer Netherlands, 86(1), pp. 1-29. doi: 10.1007/s11069-016-2671-8. 